DOI: 10.1515/LPTS-2015-0031

PHYSICAL AND TECHNICAL ENERGY PROBLEMS

\title{
IMPLEMENTATION OF THE ENERGY EFFICIENCY DIRECTIVE: OPPORTUNITIES AND CHALLENGES
}

\author{
A.Zīgurs, U.Sarma \\ Latvenergo AS \\ 12 Pulkveža Brieža Str., Riga, LV-1230, LATVIA \\ e-mail: aris.zigurs@latvenergo.lv
}

\begin{abstract}
Discussions in Latvia are ongoing regarding the optimum solution to implementing Directive 2012/27/EU of the European Parliament and of the Council of 25 October 2012 on energy efficiency, amending Directives 2009/125/EC and 2010/30/EU and repealing Directives 2004/8/EC and 2006/32/EC (Directive 2012/27/EU). Without a doubt, increased energy efficiency contributes significantly to energy supply security, competitive performance, increased quality of life, reduced energy dependence and greenhouse gas (GHG) emissions. However, Directive 2012/27/EU should be implemented with careful planning, evaluating every aspect of the process.
\end{abstract}

This study analyses a scenario, where a significant fraction of target energy efficiency is achieved by obliging energy utilities to implement userend energy efficiency measures. With implementation of this scheme towards energy end-use savings, user payments for energy should be reduced; on the other hand, these measures will require considerable investment. The energy efficiency obligation scheme stipulates that these investments must be paid by energy utilities; however, they will actually be covered by users, because the source of energy utilities' income is user payments for energy. Thus, expenses on such measures will be included in energy prices and service tariffs.

The authors analyse the ways to achieve a balance between user gains from energy end-use savings and increased energy prices and tariffs as a result of obligations imposed upon energy utilities. Similarly, the suitability of the current regulatory regime for effective implementation of Directive 2012/27/ $\mathrm{EU}$ is analysed in the energy supply sectors, where supply tariffs are regulated.

Keywords: energy efficiency, energy efficiency obligation scheme, tariff adjustment.

\section{INTRODUCTION}

Like other EU Member States, Latvia is preparing for implementation of Directive 2012/27/EU and discussing potential implementation scenarios. As we know, Directive 2012/27/EU envisages three options to achieve the end-use energy savings target [1]: 
1. To introduce an energy efficiency obligation scheme (EEOS), i.e., to oblige energy utilities to implement user-end energy efficiency measures, and each utility must thereby achieve specific energy end-use savings;

2. To implement alternative measures. In this case, various tax, public financing and fiscal stimulus instruments would be employed to achieve the energy efficiency target;

3. To combine the EEOS with alternative measures.

The Latvian government has conceptually decided that the combination of EEOS and alternative measures shall be employed in order to achieve the end-use energy savings target. Moreover, the goal is to achieve the mandatory end-use energy savings target mostly (65\%) by means of the EEOS [2].

\section{GAINS FROM ENERGY EFFICIENCY VS INCREASED ENERGY COSTS}

There is no doubt that implementation of the EEOS and fulfilment of the obligation to implement user-end energy efficiency improvement measures imposed on energy utilities will achieve certain energy end-use savings. The EEOS provides that these energy efficiency measures shall be financed by energy utilities. Thus, it may seem that the energy users should be the ones who gain: the amount of energy they consume would be reduced without any investment, and therefore, the charges to be paid for energy consumed should also go down.

Yet, the only source of income for energy utilities is the sale of energy or provision of energy supply services. Consequently, to finance measures implemented at the user end, the energy utilities will inevitably have to raise the prices of energy supplied or services provided. Energy policymakers also acknowledge the increase in energy supply costs expected as a result of the implementation of Directive 2012/27/ EU, estimating it to be $2-4 \%$. It should be noted, however, that this estimate is not based on an analysis of costs of the selected EEOS model in Latvian conditions, but rather refers to the experience of other countries.

In a general case, EEOS implementation should be modelled with a cost-benefit analysis, selecting the most expedient solution for the public at large, which may be characterised in a simplified way as the solution that fulfils the following ratio:

$$
B \geq C
$$

where $B$ stands for total gains; $C$ - for total costs.

Total gains for the public should be considered on a larger scale than mere reduction in user payments for energy, because it may reasonably include benefits that are difficult or even impossible to quantify and monetise. For instance, they include the positive effect of reduced GHG emissions, increased energy supply security and lower energy dependence. In this case, one might consider that a positive effect for the public is also achieved in the event that gains directly amenable to evaluation are 
lower than costs; in such a situation, one should select a solution ensuring the lowest exceedance in ratio (1).

Having considered the available information about forecasts of results under the scenario selected in Latvia, the apparent perception is that cost-benefit ratio (1) will be fulfilled, because the set energy end-use savings target to be achieved by means of the EEOS (6-8\%) in relative terms is specified as higher than the assumed relative increase in energy and service costs $(2-4 \%)$ as based on the experience of other countries.

However, the conclusion is premature, because it is not based on specific analytical evaluations, particular suggested guidelines for which are outlined below.

\section{IMPACT OF ENERGY EFFICIENCY MEASURES ON ENERGY PRICES AND TARIFFS}

The public organisation Latvijas siltumuzñēmumu asociācija (Latvian District Heating Association) has polled its members - district heating utilities - asking them to estimate the impact on tariffs for provided services that would result from the implementation of the imposed EEOS requirements. The utilities' evaluations ranged quite widely, estimating an increase in tariffs from 5 to $25 \%$, mostly keeping within the 9-16\% range. Furthermore, a large fraction of poll participants noted that a relatively significant part of the energy efficiency obligation could be achieved not by implementing customer energy efficiency measures but by contributing a specific amount of money to the energy efficiency fund, as permitted by Directive 2012/27/ EU.

The wide range of estimates indicates that no uniform methodology had likely been applied for the calculations. However, it should be noted that completely comparable results could not have been achieved also because even basic clarifications of how the EEOS is expected to work have not been provided yet, not to mention further details in the form of methodological guidelines necessary for EEOS-related calculations. However, even assuming that, for the aforementioned reasons, the poll cannot be considered sufficiently representative, one may forecast with relative certainty that the actual increase in energy prices and service tariffs will exceed the policymakers' forecast of $2-4 \%$ by a significant margin.

Thus, a competent and detailed analysis of EEOS implementation should be undertaken in order to evaluate expected increases in cost and identify sets of energy efficiency measures that would be suitable for balancing costs and benefits better.

Prior to the EEOS implementation, it is advisable to first carry out assessments of energy efficiency potentials. The total energy efficiency potential can be divided into market, economic, social, technical and theoretical potentials.

The market potential is the achievable reduction in energy consumption given the existing market conditions, with no stimuli or policy requirements. It can be harnessed as consumer behaviour model shift, with very cheap measures that pay back within a few years. Rational consumers harness this potential without external influence.

The economic potential can be exploited in a perfectly functional market 
economy, when energy prices give consumers the right signals, and all additional costs related to energy use and environmental quality are considered. More expensive measures are generally applied to exploiting this potential, which pay back in the intermediate term and depend largely on the costs of energy and of energy efficiency technology.

The social potential is higher than the economic potential, because its substantiation includes not only the financial gains to be achieved by the relevant energy consumer but also the gains for the public at large across environmental, energy supply security, and other aspects that are difficult to assess.

The technical potential refers to the amount of energy necessary to, using the best commercially available technologies, supply the consumer fully with the service or process for which the energy is used. The measures taken to exploit this potential are expensive, and their costs are only recouped in the long term.

The theoretical potential represents an ideal energy supply and consumption system that is virtually impossible in reality. This measure is used as a distant goal to strive for.

Practical assessments generally divide the overall energy efficiency potential into three types: technical, economic and achievable [4]. Accordingly, implementation of energy efficiency measures should be planned by progressing from those which are cheapest and can be implemented quickly (the market and economic potentials) to those which require greater investments that return slower (the social, achievable, partly even technical potentials).

An evaluation of energy efficiency potentials requires accurate performance indicators for potential energy efficiency measures. The cost-benefit analysis, therefore, should be carried out differentially for each type of energy efficiency measure.

General evaluations of potential increases in energy pricing and service tariffs - particularly if they do not rely on a unified methodological approach - are therefore not to be considered an adequate indicator of energy efficiency measure suitability.

In a general scenario, energy price and service tariff increases arising from implementation of energy efficiency measures are caused by two factors:

- Cost of investment in implementing an energy efficiency measure;

- Reduced volume of supplied energy, given the same infrastructure and ensuing permanent costs.

If energy utilities have correctly considered both factors in their estimates, it still is a narrow view, because increased energy prices and tariffs are a relative value that only shows how much more expensive a unit of energy or supply service has become. On the other hand, from the energy consumer's standpoint, what should be evaluated is not the increase in prices and tariffs but the changes in the payment charged per unit of process, service or other benefit for which the user is consuming the energy. In an ideal case, the consumer payment amount per such unit would be reduced as a result of implementation of an energy efficiency measure regardless of increased energy prices and tariffs, i.e., the following inequality would apply:

$$
P_{1} Q_{1} \geq P_{2} Q_{2}
$$


where $P_{l}, P_{2}$ refer to the cost of energy before and after the implementation of the energy efficiency measure, and $Q_{P}, Q_{2}$ characterise the energy consumption before and after the implementation of the energy efficiency measure.

In accordance with the energy potential distribution theory, energy efficiency measures ensuring fulfilment of the requirement (2) would generally exploit the market and economic potentials of energy efficiency. As specified earlier, some consumers exploit the energy efficiency market potential themselves, with no external stimuli and state policy. In the case of Latvia, we should also consider the results of the energy efficiency programmes that have already been implemented using the European Community structural fund co-financing. We may accordingly presume that, in the implementation of EEOS goals, energy utilities should also target tougher, more expensively exploitable potentials, where requirement (2) would no longer be fulfilled.

Therefore, in order to have the lowest possible exceedance of the cost-benefit balance following the implementation of the EEOS duties, the plan of the EEOS duties should grade the energy efficiency measures in an order based on the outcome of their cost-benefit evaluation. A variety of methods can be adapted for the purpose of analysing the costs and benefits of energy efficiency measures, for example, the Total Resource Cost Test - a method devised in the U.S. [5].

The test is performed for each type of measure using the formula:

$$
T R C=\frac{B A C}{T C+A C}
$$

where $B A C$ stands for Benefits of Avoided Cost, meaning the monetised total gains from reduced energy and demand (including avoided expenses on investment in generation, transmission and distribution, and variable energy production costs); TC stands for Technological Cost, meaning incremental expenses on implementing the energy consumer's equipment and assets (if current equipment is replaced before the end of its life cycle as a result of implementing an energy efficiency measure, these costs are equal to the total cost of the equipment); and $A C$ stands for Administrative Cost, representing the full cost of the implementing party's execution of the energy efficiency programme.

It is easy to conclude that an energy efficiency measure is cost-efficient and achieves the market or economic energy efficiency potential when TRC $>1$. U.S. policymakers specify TRC thresholds for various energy efficiency technologies. To stimulate the introduction of some new technologies to the market, the relevant thresholds are specified at less than 1. Furthermore, the aforementioned TRC tests for energy efficiency measures are redone annually to account for development of technologies and their falling prices. As a result, entities implementing energy efficiency programmes have clear guidelines for quantitative evaluation of energy efficiency measures and development of energy efficiency programmes.

If an analysis of the most characteristic types of energy efficiency potential 
was conducted across various energy sectors and consumption segments, differentiating the cost-benefit evaluation for each type of energy efficiency measures, both policymakers and energy utilities could plan, prioritise and focus on sets of energy efficiency measures with adequate precision, evaluating the necessary investments, expected results, and the ensuing impact on energy prices and tariffs.

\section{ALLOCATION OF EEOS OBLIGATIONS}

Currently, Latvia only has a draft energy efficiency target distribution between the EEOS and alternative measures within the framework of the total energy efficiency target stipulated in Directive 2012/27/EU. However, with regard to the distribution of the EEOS target by energy subsectors and energy consumption segments, only the intentions of policymakers are known.

Available information shows that the plan is to include energy utilities that supply electricity, natural gas and district heating in the EEOS. Outside this obligated group, there are utilities that supply primary energy resources to final consumers. Implementation of such an approach completely deforms the allocation landscape of EEOS obligations. It follows from the overall final energy consumption structure of Latvia [6] that, if the energy consumed in the transport sector is subtracted from the total final energy consumption (since this amount is not included in the country's total energy efficiency target calculation), the amount of energy supplied by energy utilities subject to the EEOS constitutes about $55 \%$ of the final consumption specified in the energy efficiency target (Fig. 1). Consequently, $45 \%$ of the final energy consumption is supplied by utilities that will not be bound by the energy efficiency obligation.

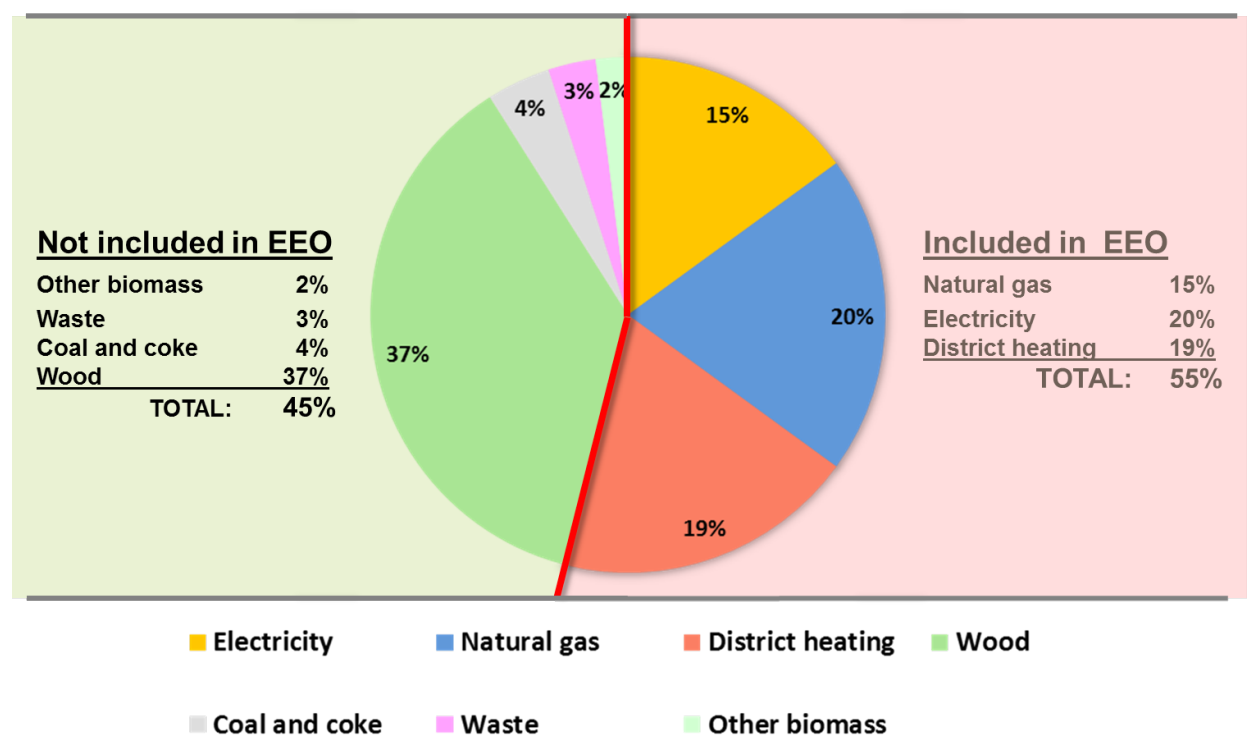

Fig. 1. Inclusion of the final energy consumption suppliers in the EEOS (without the transport sector). 
If distribution of EEOS obligations is implemented in accordance with the envisaged scenario, the cost burden that the energy utilities included in the EEOS are forced to transfer to consumers will be divided in a highly discriminatory fashion. The energy utilities will be obliged to implement measures for achieving the overall energy end-use savings; and they will be able to implement these measures for any consumer. At the same time, they will be able to transfer the energy efficiency measure costs only to those consumers who receive energy from them. As a result, gains from the EEOS will be available to all energy consumers but paid for only by those who represent $55 \%$ of the total final consumption. In this situation, one may presume with certainty that the costs in excess of gains for consumers receiving energy from EEOS utilities will be far from balanced.

Moreover, the allocation of EEOS duties in the district heating sector will bring about a second negative aspect. The EEOS currently stipulates a very high threshold for including district heating utilities - the amount of thermal energy supplied per year should be 40,000 MWh [3]. In this case, the EEOS would include the utilities that provide about $70 \%$ of the total thermal energy supplied to district heating. The number of thermal energy utilities outside the EEOS is high, while the amount of energy supplied by each is small. This factor will significantly deform the non-equitable distribution illustrated in Fig. 1 even further, because the amount of energy that would not be subject to the EEOS will increase by about 6 percentage points, as a result of which the EEOS obligations will be imposed on utilities that supply less than half (or about $49 \%$ ) of the total final energy consumption.

The proposed threshold for including the district heating utilities in the EEOS will also produce a significant risk in the district heating sector itself. An inevitable increase in prices and tariffs for thermal energy supplied by EEOS utilities will cause some consumers or even groups of consumers to reject the district heating services and establish local heating sources or small district heating systems. Consequently, as the amount of energy supplied by EEOS utilities is further reduced, the costs would continue to loom ever higher above benefits for remaining users. This will bring about a positive feedback loop described in system dynamics [7]. The positive feedback in this case refers not to a positive outcome of the process but to selfreinforcement of the process, escalating to saturation.

The aforementioned choice of allocating EEOS obligations by policymakers is understandable if we consider it from the point of view of institutions that will have to administrate the EEOS. Certainly, it is easier to administrate a lower number of larger energy utilities, and this requires fewer administrative resources. Another argument in favour of such a choice is avoiding administrative and cost burdens on a large number of small utilities.

However, considering that implementation of the proposed EEOS scenario in Latvia will result in the energy supplied by energy utilities not subject to the EEOS exceeding one half of the total final energy consumption, such a solution is unacceptable from the point of view of equitable distribution of cost burdens imposed on energy consumers.

Therefore, despite requiring more complex and resource-intensive administration of the EEOS, there is a reason to expand the EEOS in two directions, namely: 
- to include those utilities that supply primary resources for final consumption in the EEOS;

- to remove the threshold for inclusion of district heating utilities in the EEOS.

\section{REGULATORY REGIME}

If energy is sold on the market, as is the case in electricity supply, then energy utilities are motivated to fulfil the obligations under the EEOS as cost-effectively as possible. The situation is different in the energy sectors where energy is offered for sale at regulated tariffs, for instance, thermal energy supply for district heating.

Latvia applies the Cost Plus method to thermal energy supply regulation. On the one hand, this method requires thorough calculation of all costs and check-up of the relevant supporting documents. However, on the other hand, the regulator has rather limited instruments to evaluate effectiveness of costs based on supporting documents. Part of the costs may be evaluated using technically verifiable and measurable indicators. For instance, it is possible to check if fuel costs are substantiated by evaluating the fuel consumption ratio and comparing it to similar indicators and good practice. The regulator has no basis for doubting other cost substantiations and forecasts provided by utilities, however. For instance, this applies significantly to investment costs, including investments in fulfilment of the energy efficiency obligation.

The current tariff calculation methodology does not stipulate any cost item to ensure recovery of costs arising through fulfilment of the EEOS [8]. One would expect the relevant cost item to be included in the methodology sooner or later, but given the regulatory approach practiced in Latvia, it will not motivate energy utilities to seek more cost-effective solutions, as they will be able to include in the tariff calculation the cost of any energy efficiency measure that they have implemented.

The regulator will lack argumentation to doubt the costs of a given measure. The only motivation for seeking more cost-effective solutions is the efforts of thermal energy utilities to keep their thermal energy market and attract new users, because, although the thermal energy tariff is regulated and provision of this public utility service is characterised by monopolistic elements, any increase in tariffs would be targeted at reducing thermal energy sales further.

In turn, the maximum borderline case that the regulator itself will be able to use as a lawful restriction would be the amount of the EUR/MWh payment specified in legislation, which an energy utility would be obliged to contribute to the energy efficiency fund for each "non-economised" energy unit if it fails to fulfil its individual duty within the EEOS framework.

Therefore, one may expect the current regulatory regime to be another factor that will effectively shift the cost-benefit ratio away from the balance. Regulatory regime improvements should be sought in relaxing the regulatory regime, i.e., transitioning from the current strict regulation and the ex ante principle towards regulation relying more on the market, benchmark and ex post principles. 


\section{CONCLUSIONS}

To achieve a greater balance between public benefits and additional costs from meeting the requirements of Directive 2012/27/EU, the following steps are recommended:

- To carry out an assessment of the conventional types of energy efficiency potential from the perspectives of the energy sectors and consumption segments;

- To carry out a cost-benefit analysis for each type of energy efficiency measure;

- To include in the EEOS those energy utilities that supply primary energy resources for final consumption;

- To abolish the threshold for including district heating utilities in the EEOS;

- In the district heating sector, to proceed towards relaxation of the regulatory regime and its approximation to market principles.

\section{REFERENCES:}

1. European Parliament and the Council Directive 2012/27/EU on energy efficiency, amending Directives 2009/125/EC and 2010/30/EU and repealing Directives 2004/8/EC and 2006/32/EC [2012] OJ L 315.

2. LR Ekonomikas ministrija. (2013). Koncepcija par Eiropas Parlamenta un Padomes 2012. gada 25.oktobra Direktīvas 2012/27/ES par energoefektivitāti, ar ko groza Direktīvas 2009/125/EK un 2010/30/ES un atcel̦ Direktīvas 2004/8/EK un 2006/32/EK, prasību pārņemšanu normatīvajos aktos 2013.

3. LR Ekonomikas ministrija. (2013). Ziņojums par Eiropas Parlamenta un padomes Direktīvas 2012/27/ES (2012. gada 25. oktobris) par energoefektivitāti, ar ko groza Direktīvas 2009/125/EK un 2010/30/ES un atcel̦ Direktīvas 2004/8/EK un 2006/32/EK 7.panta prasību izpildi.

4. Nadel, S., Shipley, A. and Elliott, R.N. (2004). The Technical, Economic and Achievable Potential for Energy Efficiency in the U.S. - A Meta-Analysis of Recent Studies. Washington, DC: American Council for an Energy-Efficient Economy [ACEEE].

5. 2013 California Energy Efficiency Potential and Goals Study. Walnut Creek CA: The Navigant Consulting, Inc.

6. Ministry of Economics of the Republic of Latvia. (2013). Latvian Energy in Figures. Riga.

7. Blumberga, A., Blumberga, D., Bažbauers, G., Davidsen, P., Moxnes, E., Dzene, I., Barisa, A., Žogla, G., Dāce, E., Bērziṇa, A. (2010). Sistēmdinamika vides inženierzinātnu studentiem. Rīga: Rīgas Tehniskās universitātes Vides aizsardzības un siltuma sistēmu institūts. ISBN 9789934819612.

8. Sabiedrisko pakalpojumu regulēšanas komisija. (2010). Siltumenerǵijas apgādes pakalpojumu tarifu aprēķināšanas metodika. Rīga. 


\title{
ENERGOEFEKTIVITĀTES DIREKTĪVAS IEVIEŠANA - IESPĒJAS UN IZAICINĀJUMI
}

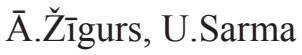 \\ Kopsavi $1 \mathrm{kums}$
}

Pašlaik Latvijā noris diskusijas par optimālo risinājumu Direktīvas 2012/27/ ES par energoefektivitāti ieviešanai. Energoefektivitātes paaugstināšana dod nozīmīgu ieguldījumu apgādes drošībā, konkurētspējā, dzīves kvalitātes pieaugumā, energoatkarības un SEG emisiju samazināšanā. Tomēr Direktīva jāievieš pārdomāti un ir rūpīgi jāizvērtē visi šì procesa aspekti.

Pētījumā analizēts scenārijs, kurā nozīmīgu daļu no energoefektivitātes mērķa paredzēts sasniegt, uzliekot energoapgādes komersantiem pienākumu īstenot energoefektivitātes pasākumus lietotāju pusē. Enerğijas gala patēriṇa samazinājumam būtu jāsamazina lietotāju maksājumi par enerǵiju, bet šie pasākumi prasīs zināmus ieguldījumus. Pienākuma shēma paredz, ka šie ieguldījumi ir jāapmaksā energoapgādes komersantiem, bet faktiski tos apmaksās lietotāji, jo energoapgādes komersantu vien̄̄gais ienākumu avots ir lietotāju maksājumi par enerǵiju un tātad izdevumi par pasākumiem tiks iekḷauti enerǵijas cenās un pakalpojumu tarifos.

Autori analizē kā tuvoties līdzsvaram starp lietotāju ieguvumiem no enerǵijas gala patēriņa samazinājuma un enerǵijas, un cenu un tarifu pieaugumu energoapgādes komersantiem uzlikto pienākumu rezultātā. Tāpat novērtēta pašreizējā regulācijas režīma piemērotība efektīvai Direktīvas ieviešanai tajās energoapgādes jomās, kur energoapgādes tarifi tiek regulēti.

29.06.2015. 